\title{
An Empirical Examination of Success Model SAS Application on Teritory of Bengkulu Treasury Office
}

\author{
Puji Astuti $^{*}$ and Willy Abdillah ${ }^{2}$ \\ ${ }^{1,2}$ University of Bengkulu, Bengkulu, Indonesia
}

\begin{abstract}
This study examines determinants of successful of SAS application by reviewing user perception that adapted successful model of information system developed by DeLone and McLean (1992), which system quality, information quality, system use, user satisfaction, and individual impact. Primary data is obtained by questionaries filled by 100 respondents from units in the teritory of of treasury office of Bengkulu. Data analyzed by using Partial Least Square (PLS) as one of the alternative methods of Structural Equation Modeling (SEM). The results show that quality of the system and quality of information affects user satisfaction but did not affect use of the system. Use of the system affected satisfaction of user and level satisfaction of user would affect the use of the system. User satisfaction affects the impact of the individual.
\end{abstract}

Keywords: Individual Impact, Information Quality, Information Systems Success, System Quality, System Use, User Satisfaction

\section{INTRODUCTION}

The information technology system that are applied in organizations are components that become a part of organizations and together with individuals in organizations interact with each other and use the information technology system to be able to carry out several activities and obtain job results that are more effective and efficient. According to Rahadi (2007), the use of the technology system today is already widely applied in government sectors, specifically in providing service to the people.

The use of information system technology that are applied in government institutions, one of them is the application of information technology systems in the national finance management field. This information technology system application has an important enough role for being able to produce quality financial reports for the creation of accountability. A good financial report according to the valid reporting standards are produced by the process of a good accounting information system.

The Accounting Information System is a system that gathers, records, saves, and processes data for producing information for the purpose of decision making (Romney and Steinbart, 2015: 10), with the presence of computer technology progress and information that already has an impact to the ways of accounting recording, computerized Accounting Information Systems makes it possible for the

* Corresponding author. Email address: pujiastuti1116@gmail.com 
user of a financial report to be able to see financial reports every time faster and more accurately (Istianingsih and Wijanto, 2008b).

With the presence of the Minister of Finance Regulation No. 161/PMK.05/2013 about the Place and Responsibility of the Treasurer in the National Income Spending Budget and the Treasury Director General Regulation Number PER-3/PB/2014 about Technical Instructions of Administration, Bookkeeping and Financial Responsibility, the treasurer in the working unit that manages National Income Spending Budget funds in implementing administration activities are obliged to use the application that is developed by the Treasury Directorate General of the Finance Ministry of the Republic of Indonesia.

Early in the year 2015 the Treasury Directorate General of the Finance Ministry of the Republic of Indonesia released a SAS (Satker Application System) application for finance administration that must be used by the treasurer in the working units that manages the funds of the National Income Spending Budget (http://sahabatsatker.bookcom). In its implementation this SAS application has already been implemented development for perfection. The cause of this is that in its use there are still problems and obstacles that are often experienced by Treasurers in recording bookkeeping using this SAS application (www.bendaharakotabaru.blogspot.co.id).

In the implementation of information system technology, what is most expected is the success of the information system technology in its implementation (Jogiyanto, 2007: 1). The use of information technology for developing an information system is able to provide an added value to the organization if successfully implemented (Radityo and Zulaikha, 2007) and the measure of success of an information system is very important to organizations (Myers et al, 1997).

DeLone and McLean (1992) expressed the measure of the information system success model that is known as the D\&M IS Success Model. This model reflects the dependence from six measures of success of the information system. The six elements or measuring factors from this model are system quality, information quality, use, user satisfaction, individual impact and organization impact. This success model is based on process and causal relations from information system measuring dimensions independently but the measuring as a whole influences each other. From this process and causal model it is able to be explained that the system quality and the information quality independently and simultaneously influence the use and the satisfaction of the user. The size of use is able to influence user satisfaction positively and negatively. The use and user satisfaction influences individual impact and then influences organization impact.

This D\&M IS Success Model receives much attention by researchers such as Seddon (1997), McGill et al. (2003) and Livari (2005). Yet, the above research show inconsistencies in empirical tests between each other.

Several research shows results that system quality and information quality are predictors that are significant to user satisfaction, use and individual impact (Mulyono, 2009 ; Wahyuni, 2011 ; Tan, Suyatno and Aliyah, 2015). Other research 
shows that system quality and information are significant predictors to user satisfaction but not significant to system use (McGill et al., 2003; Livari, 2005) The research results of McGill et al. (2003) also show that the satisfaction of end users of an information system plays a significant role in determining the use of the application system. With the inconsistency of empirical test results to the D\&M IS Success Model, a chance is open for continuous developing in different research objects. Other than that, previous research does not limit in the character of system use that is tested if the system is used in mandatory or voluntary objects.

This research will implement a success test of the SAS application use that is a mandatory system using the D\&M IS Success Model (1992) through the perception of its user or operator, by observing the relation between variables according to the model. In this research, the D\&M Success Model (1992) variable that will be studied is a system quality variable, information quality, use, user satisfaction, and individual impact. By implementing tests up to the individual impact, this research obtained empirical proof about factors that influences the success of the SAS application use in Work Units in the work area of the Bengkulu Treasury Office based on the D\&M Success Model (1992). Study in this research is expected to be able to become suggestions for the development institution of the SAS application in the effort of system development and also provide suggestions for system users in the effort of increasing its productivity and performance through the use of the SAS application so a financial report that is accurate, reliable, and on time is able to be produced.

\section{LITERATURE STUDY AND HYPOTHESIS DEVELOPMENT Accounting Information System}

The accounting information system is a group of several types of resources such as humans and also the instruments that are designed for converting financial data and also other data to become information that are useful to the user and its users (Bodnar \& Hopwood, 2010: 3).

According to Widjajanto (2001:4), the accounting information system is array of forms, notes, instruments including computers and their equipment and communication devices, implementation power and reports that are coordinated closely that are designed for transforming financial data into information that the management needs.

The accounting information system consists of five components (Romney and Steinbart, $2015: 11$ ), which are:

a. People that operate the system and implement several functions.

b. Procedures, neither manual nor which are automated, that are involved in gathering processing, and saving data about organizational activities.

c. Data about the business process of the organization.

d. Software that are used for processing organization data.

e. Information technology infrastructure, including computers, supporting equipment and equipment for network communication.

\section{SAS Application}


The SAS (Satker Application System) is an application that is used for creating Paying Order Letters and also some other integrated functions. Paying Order Letters are documents that are published by the Signing Official of Paying Order Letters for liquidating funds that are sourced from the List of Budget Implementation. In other words these Paying Order Letters are used by fund managing working units of the National Income Spending Budget for liquidating their funds through the Treasury Service Office.

The SAS application is developed by the Treasury System Directorate of the Treasury Directory General of the Indonesian Ministry of Finance, which is officially released in the official website of the Treasury Directory General which is djpbn.kemenkeu.go.id. This SAS application began to be officially used early in the year 2015 exactly as a replacement for the previous application which is a Paying Order Letter application that also functions for creating Paying Order Letters yet without other additional functions. This SAS application consists of a combination of several application modules, among others:

a. Treasury Institute Reporting System module which is an application for creating responsibility reports of the institute treasury of the fund management of the National Income Spending Budget.

b. National acceptance confirmation application which is an application for creating computer data archives of national acceptance confirmation to the National Treasury Service Office.

c. and cash planning application that is used for creating computer data archives, specific cash planning for working units that use Payment Order Letters with a net value above 1 (one) billion.

\section{DeLone \& McLean Information System Success Model}

One of the models that is used as a framework for the success of conceptualization and actualization of the information system is the model that is developed by DeLone and McLean (1992), which is known as the DeLone \& McLean Information System Success Model. The model that is proposed by DeLone \& McLean (1992) is a model that focuses on the implementation success in the organization level that is based on causal relations and process from information system success measuring elements that are in this model. The basic DeLone \& McLean Information System Success Model is able to be seen in Figure 1 as the following: 


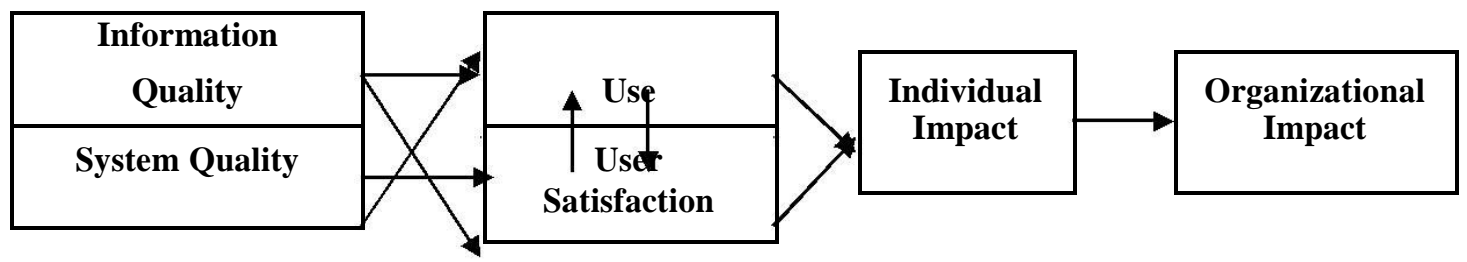

Figure 1 DeLone \& McLean Information System Success Model (1992)

Source : DeLone \& McLean (1992)

From the figure above, it is able to be explained in short that the success of the information system is shown in six dimensions which are: system quality, information quality, user satisfaction, use, individual impact, and organizational impact. This proposed model reflects dependence from System Quality and Information Quality which then independently and simultaneously influence in the use element and user satisfaction. The amount of use is able to influence the amount of user satisfaction positively and negatively and vice versa. And use and user satisfaction influences individual impact and then influences the impact of organizational impact.

Based on critics that are accepted and also based on the development of the information technology system and its environment of use, DeLone and McLean (2003) renew their model by widening it. In this renewed model, DeLone and McLean added a service quality dimension and combined two dimensions: individual impact and organizational impact to become the net benefit dimension so it becomes the model as seen in figure 2 .

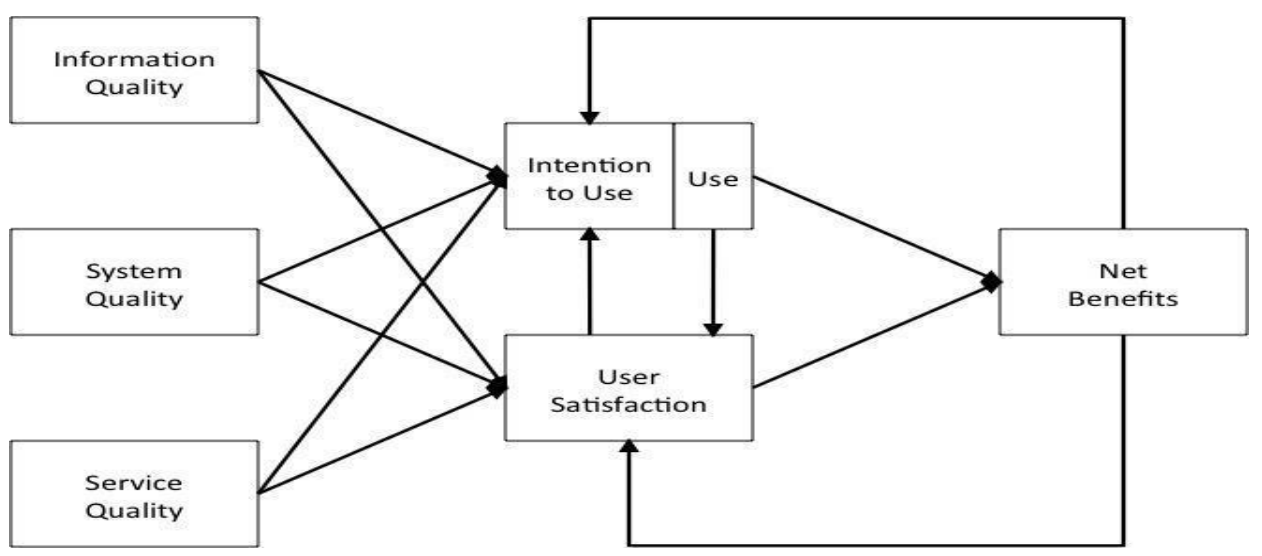

Figure 2 DeLone \& McLean Information System Success Model renewed (2003)

Source: DeLone \& McLean (2003)

This renewed model is able to be divided into three components: system creation, system use and impact from system use. The system creation component is measured with three quality dimensions: information quality, system quality, and service quality; the system use component is measured with two dimensions: use and user satisfaction as for the impact from system use is measured with two dimensions: individual impact and organizational impact/ net benefit.

\section{Measures of Information System Success}


In the success model of the DeLone \& McLean information system (D\&M IS Success Model), system quality measures technical success, information quality measures semantic success and use, user satisfaction, individual impact, and organizational impact measures effectiveness (Jogiyanto, 2007:8) Mason ( in DeLone and McLean, 1992) states that production quality and technical level is measured by its system quality production. The quality of products that are results of production in the semantic level is measured with information quality. In the effectiveness level, the effectiveness of the receiver is measured by use from its system, effectiveness of influence in its receiver is measured with user satisfaction and individual impact and the influence to its system is measured with organizational impact.

\section{Information System Quality}

System quality is used for measuring the quality of its own information technology system (Jogiyanto,2007:12). In the DeLone and McLean success model (1992), system quality measures technical success. System quality needs indicators for measuring the amount of quality from the information system.

For measuring system quality, Srinivasan (in DeLone and McLean,1992) uses the measures: respond time, system flexibility, system access. While Bailey and Pearson (in DeLone and McLean,1992) uses the measures: comfort, flexibility, system integration and respond time and McGill et al. (2003) uses the measuring elements:, portability, reliability, understandability and user friendliness. economy Information Quality

Information quality is a measure of output quality from the information system (Jogiyanto,2007:15). Rai et al. (2002) stated that information quality is an output quality in the form of information that is produced by the information system that is used.

In relation with this information quality, Ivari and Koskela (in DeLone and McLean,1992) uses three pieces of construct for measuring information quality, which are construct informativeness, accessibility and adaptability. Informativeness consists of item relevance, comprehensiveness, recentness, accuracy and credibility. Construct of accessibility consists of convenience and timeliness. While McGill et al. (2003), for rating information quality uses the measuring elements: accuracy, timeliness, relevance, informativeness and competitiveness.

Use

Jogiyanto (2007:19) differentiates use into information use and system use which means information use and use from the information system itself. The concept of use from an information system is able to be seen from several perspectives, which are actual use and perceived use or reported use.

According to McGill et al. (2003), the use of the information system that is already developed refers to how often the user uses the information system. The more often the user uses the information system, it is usually followed by the higher degree of learning that the user obtains about the information system.

The D\&M IS Success Model empirical test that is implemented by Livari (2005) in the financial information system and accounting that are obliged to be 
used in the Oulu city council, the measure of use in his research is by using the actual use perspective. Question items for measuring actual use consists of forms from daily use time items and frequency of use.

\section{User Satisfaction}

User satisfaction is the user response to the use of information system output (Jogiyanto, 2007:23). According to Seddon and Kiew (1994), user satisfaction is a clean emotion from happy or unhappy in accepting the information system from the whole benefit that is expected by somebody where the emotion is produced from interactions with the information system.

For measuring user satisfaction, McGill et al. (2003) in their research uses the measure: system efficiency, system effectiveness, and satisfaction as a whole. While Sanders and Courtney (in DeLone and McLean, 1992) uses a whole satisfaction measure and decision making satisfaction.

\section{Individual Impact}

Individual impact is an effect of information to the behavior of the user (Jogiyanto,2007:28). Impact has a close relation with performance, which is increasing the performance of an individual information system user.

For measuring impact. Livari (2005) uses 6 items that are adapted from perceived usefulness by Davis (1989). The mentioned perceived usefulness are the speed of finishing assignments, work achievement, productivity, effectiveness, simplicity of work, and use in work.

The influence of system quality, information quality to system use

System quality shows its production quality and information quality shows the quality of the product that is produced from its information system. These two qualities determine the attitude of the system user, depending on the system quality and its information quality, the system user uses or does not use (Mason in DeLone and McLean, 1992) Related to that factor, DeLone \& McLean (1992) stated that information quality influences the use of the information system.

The research of Mulyono (2009) and Wahyuni (2011), the results show empirical proof that system quality has a positive influence to use and information quality has a positive influence to use. This means the higher the system quality, the use intensity is also more and more higher.

Based on the explanation above, the research hypothesis that is defined is as the following:

\section{$H_{1}$ : Information system quality has a positive influence to system use \\ $\mathrm{H}_{2}$ : Information quality influences positively to system use}

\section{The Influence of Information System Quality to User Satisfaction}

System quality is one of the first dimensions in the information system success model of DeLone and McLean. System quality shows the production quality and is used for measuring the system technology quality itself. (Jogiyanto, 2007:12). DeLone \& McLean (1992) stated that system quality influences user satisfaction.

In its testing, Seddon and Kiew (1994) found that there is a positive relation between system quality and user satisfaction. If the information system quality is 
good according to the perception of its user, they will tend to feel satisfied in using the mentioned system. The higher the quality of the information system that is used, it is predicted that it will influence to the more and more higher levels of end user satisfaction of the information system.

System quality has a positive influence to the satisfaction of the system user. The larger the system quality, the user satisfaction will also be higher. This statement is consistent with the research results of Mulyono (2009), Istianingsih and Wijanto (2008b), Livari (2005), and McGill et al. (2003). Based on the above explanation, the hypothesis is able to be stated as the following:

\section{$\mathrm{H}_{3}$ : Information system quality influences positively to system use satisfaction}

\section{The Influence of Information Quality to User Satisfaction}

Information quality measures output quality from the information system. If the information that accounting software produces is more accurate, on time, and has a good reliability, it will increase the trust of the system user. In the D\&M IS Success Model (1992) it is explained that information quality will influence user satisfaction (DeLone and McLean, 1992).

Livari (2005) tested empirically the D\&M IS Success Model with the financial information system object and accounting that are obliged to be used in the city council of Oulu, Finland. The results show that information quality is a significant predictor to user satisfaction.

Istianingsih and Wijanto (2009) in their research also summarizes that information quality is proven significantly to have a positive influence to system user satisfaction. This means the higher or better the information quality that is produced by the system the level of system user satisfaction is also higher.

Information quality has an influence to system user satisfaction. An increase in information quality that is provided in the system will increase the system user satisfaction. This statement is consistent with the research results of Wahyuni (2011), Mulyono (2009), Istianingsih and Wijanto (2008a), Istianingsih and Wijanto (2008b), Livari (2005) and Seldon and Kiew (1994). Based on the explanation, the hypothesis is able to be stated as the following:

\section{$\mathrm{H}_{4}$ : Information quality has a positive influence to system user satisfaction}

\section{Influence of system use to User Satisfaction}

User satisfaction is a clear emotion from happy or unhappy in accepting the information system and the whole benefit that is expected by somebody where those emotions are produced by interactions with the information system (Seddon and Kiew, 1994). If the information system user is confident with the system quality that he or she uses and feels using the mentioned information system is not difficult, they will believe that the use of the mentioned system will present a large benefit.

A positive experience because of use will cause a higher user satisfaction (DeLone \& McLean, 2003). The research implemented by Wahyuni (2011) and Mulyono (2009) shows empirical proof that system use has a positive influence to system user satisfaction. This means that the higher the system use, the higher the 
system user satisfaction. Based on the above explanation the research hypothesis that is defined is as the following:

\section{$H_{5 a}$ : System use has a positive influence to information system user satisfaction}

\section{Influence of user satisfaction to system use}

According to DeLone and McLane (2003), use and user satisfaction are very close in relation. Use has to precede user satisfaction as a process, but a positive experience because of use will cause a higher user satisfaction as a causal. Simultaneously, an increase in user satisfaction will cause an increase in use interest and then will use. This means that user satisfaction has a positive influence to use.

McGill et al. (2003) in their research shows that user satisfaction influences use intensity. The mentioned statement is consistent with the research results that are implemented by Wahyuni (2011) and Mulyono (2009). Based on the above explanation, the research hypothesis that is defined is as the following:

$H_{5 b}$ : System User Satisfaction has a positive influence to system use Influence of system use to individual impanct

Individual impact is the effect from information to user behavior. Impact is closely related with performance which is an increase of individual performance. (DeLone and McLean, 1992). The use of the information system that is already developed refers to how often users use the information system. The more users use the information system, is usually followed by the more degree of learning that users obtain about the information system (McGill et al., 2003). This increase of learning degree is an indicator that there is an influence of system presence to user quality (individual impact)

Radityo and Zulaikha (2007) implemented research for testing the use of the Website Based Academic Information System application in the Faculty of Economics Diponegoro University. Samples are obtained from 200 persons that consists of students and lecturers in the Faculty of Economics Diponegoro University. The results show that use has a positive influence to individual impact.

Mulyono (2009) in his research summarizes that system use has a positive influence to individual impact. The higher the system use, it will provide a higher impact for individual users. Based on the explanation above, the research hypothesis that is defined is as the following:

H6 : System Use has a positive influence to individual impact Influence of system user satisfaction to individual impact

The effectiveness of influence in the information system receiver is measured with user satisfaction and individual impact. The research results implemented by Livari (2005) found proof that user satisfaction becomes the strongest predictor to individual impact. This means user satisfaction has an influence to individual impact.

Another research that is consistent with the research implemented by Livari (2005) is the research implemented by Wahyuni (2011), Mulyono (2009), Istianingsih and Utami (2009), and McGill et al. (2003), their research shows results that user satisfaction influences positively to individual impact. The higher 
the user impact level, the higher individual impact. Based on the explanation above, the hypothesis that is able to be stated is as the following:

\section{impact}

$\mathrm{H}_{7} \quad$ : System User Satisfaction has a positive influence to individual

\section{Research Framework}

Based on the hypothesis explanations above, the framework in this research, the researcher adapts the framework from the DeLone and McLean information system success model (1992), but the researcher does not implement a model test as a whole because the organizational impact measure is not able to be accommodated in this research.

The framework in this research is able to be seen in Figure 3 as the following:

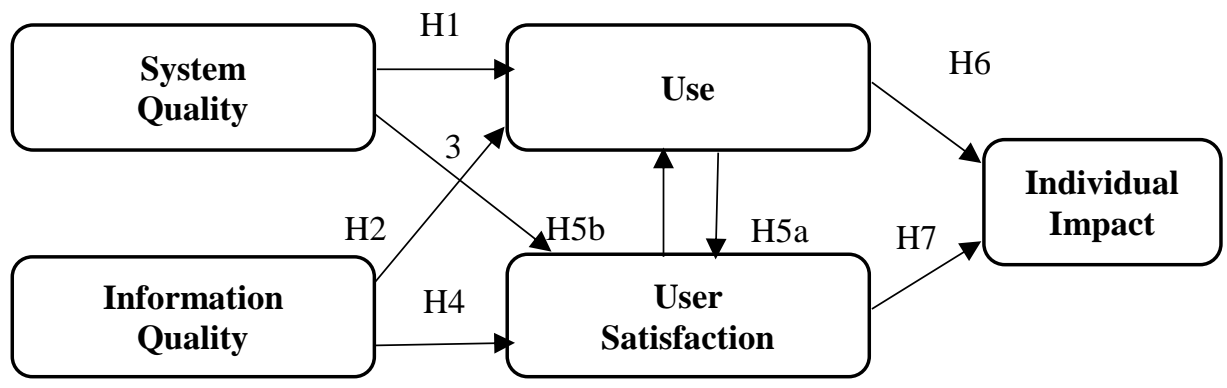

Figure 3 Research Framework

Source: DeLone \& McLean Model Adaptation (1992)

The model process and causal relation in picture 2.3 above, is able to be explained as the following: system quality and information quality independently and simultaneously influences neither use nor user satisfaction. The amount of use is able to influence user satisfaction positively or negatively and vice versa. Use and user satisfaction influences individual impact (DeLone and McLean, 1992).

The model in Figure 3 above shows vice versa directions from user satisfaction and use. Mutual influences such as this is unable to be tested simultaneously (Livari, 2005), so it has to be tested two times which is to become model 1 such as in Picture 2.4 that assumes influence from use to user satisfaction $\left(\mathrm{H} 5_{\mathrm{a}}\right)$ and model 2 such as in Figure 5 that assumes influence from user satisfaction to use $\left(\mathrm{H} 5_{\mathrm{b}}\right)$. 


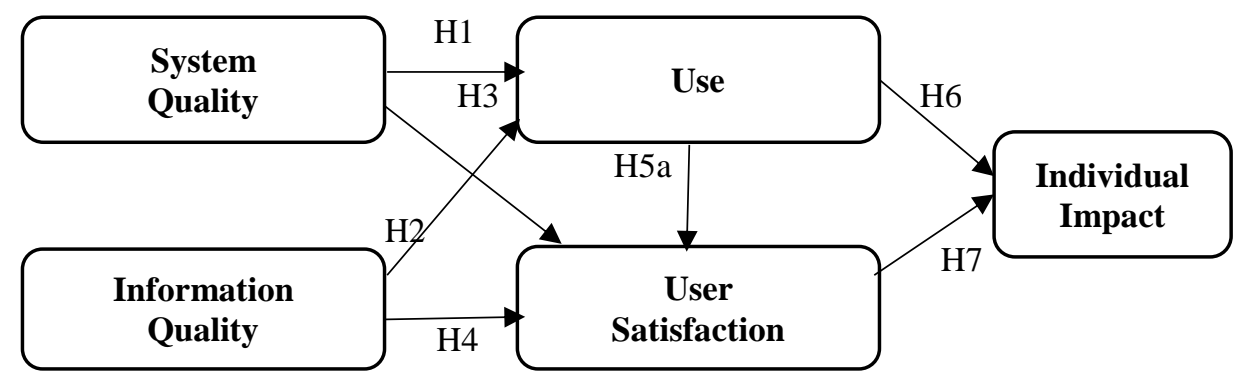

Figure 4 Model Research Model 1

Source : DeLone \& McLean (1992), Livari (2005)

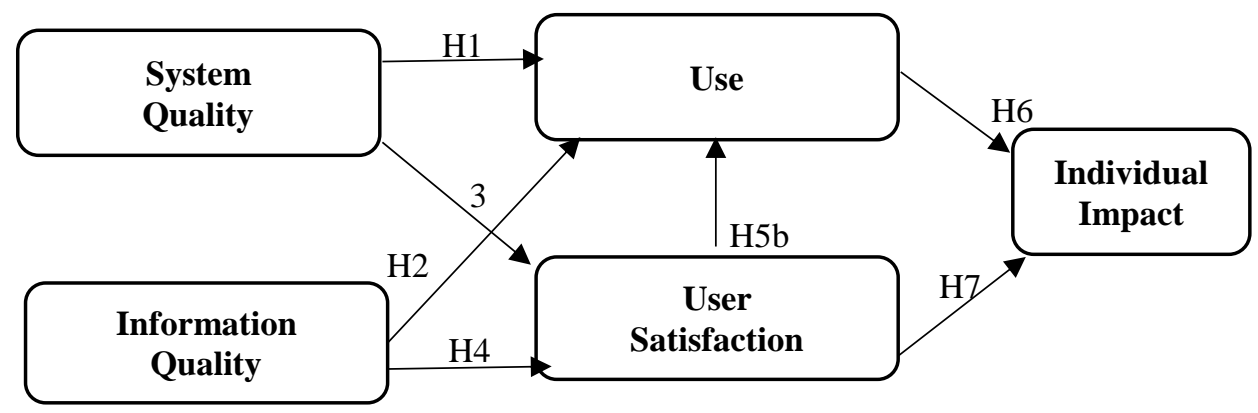

Figure 5 Model Research Model 2

Source : DeLone \& McLean (1992), Livari (2005)

\section{RESEARCH METHOD}

The type of research that will be implemented in this research is explanatory research. This research uses a design survey with questionnaires as a data gathering instrument. Variable measuring in this research consists of independent and dependent variables. Independent variables consists of information quality and information system quality. Dependent variables consists of use, user satisfaction, and individual impact. All measuring items of every variable or latent construct uses five likert scale points that are adapted from DeLone and McClean (1992).

The population in this research are all the treasurers or financial management staff in the working area of the Bengkulu National Treasury Central Office that uses the SAS application spread into 303 work units in the working area of the Bengkulu National Treasury Central Office. Samples as many as 120 respondents are chosen with a purposive sampling technique with the criteria as the following:

a. Treasurer that has a double duty as a SAS application operator.

b. Financial Management Staff that is on duty as a SAS application operator.

The validity, reliability tests and hypothesis test uses a PLS method with the aid of the application SmartPLS 3. 


\section{ANALYSIS}

The gathering of research data was implemented initially on November 09 2015 until January 09 2016. Research data is gathered by giving questionnaires to respondents directly. The illustration dispersion and questionnaire pickup in this research is illustrated such as in Table 1 below:

Table 1 Dispersion Analysis Results and Questionnaire Pickup

\begin{tabular}{clc}
\hline No & \multicolumn{1}{c}{ Questionnaire Dispersion Illustration } & Jumlah \\
\hline 1 & Questionnaires that are spread to respondents & 120 \\
2 & Questionnaires that did not return & 17 \\
3 & Questionnaires that returned but incomplete & 3 \\
4 & Questionnaire that are able to be processed & 100 \\
\hline
\end{tabular}

Source: Primary data processing results 2016

Table 1 shows that from 130 questionnaires that are spread, questionnaires that are not returned by respondents are as many as 17 questionnaires or as large as $14.2 \%$, questionnaires that came back but are not complete are as many as 3 questionnaires or as large as $2.5 \%$ and questionnaires that are able to be processed are as many as 100 questionnaires or as large as $83.3 \%$. Questionnaires that returned but are in the incomplete category are not included in the data analysis, so the questionnaires that are analyzed in this research are as many as 100 questionnaires.

General respondent characteristics in this research are illustrated based on: gender, age, education level, and respondent position. As for respondent characteristics in this research is shown in the following Table 2:

Tabel 2 Respondent Characteristics

\begin{tabular}{|c|c|c|c|}
\hline No & Category & Total & Percentage $(\%)$ \\
\hline \multirow[t]{5}{*}{1} & Age & & \\
\hline & a. $<25$ Years & 0 & 0 \\
\hline & b. 25-30 Years & 29 & 29 \\
\hline & c. 31-35 Years & 39 & 39 \\
\hline & d. $>35$ Years & 32 & 32 \\
\hline \multirow[t]{3}{*}{2} & Gender & & \\
\hline & a. Male & 58 & 58 \\
\hline & b. Female & 42 & 42 \\
\hline \multirow[t]{5}{*}{3} & Education Level & & \\
\hline & a. Post Graduate & 2 & 2 \\
\hline & b. Graduate & 74 & 74 \\
\hline & c. Diploma & 5 & 5 \\
\hline & d. High School & 19 & 19 \\
\hline \multirow[t]{3}{*}{4} & Position & & \\
\hline & $\begin{array}{l}\text { a. Treasurer that has a double duty as } \\
\text { as a SAS application operator }\end{array}$ & 52 & 52 \\
\hline & $\begin{array}{l}\text { b. Financial Management Staff that } \\
\text { is on duty as a SAS application } \\
\text { operator }\end{array}$ & 48 & 48 \\
\hline
\end{tabular}


Based on age, the most respondents are in the range of 31-35 years old as many as 39 persons or as large as $39 \%$. Based on gender, the total respondents in this research is well balanced between male and female operators. Based on education level, the graduate level dominates as large as 74\%. Reviewed from position, it is seen that the dominant treasurer operates the SAS application because the treasurer has a responsibility for implementing administration, bookkeeping and responsibility of the finance of the working unit. So every time a transaction occurs in the working unit, who is assigned for data input in the SAS application, of course should be directly implemented by the treasurer.

\section{Convergent Validity Test}

The convergent validity is rated with the output results from outer loading and Average Variance Extracted (AVE). Based on the results of the PLS algorithm test it is seen that all model indicators that have outer loading is larger than 0.70 so it is able to be summarized that the mentioned indicator fulfills the validity criteria. Likewise also with the AVE parameter, it is seen that all constructs have fulfilled the criteria.

\section{Discriminant Validity Test}

The discriminant validity test is rated based on cross loading measure with its construct. The indicator is stated to be valid discriminantly if the cross loading value is > 0.70 in one variable (Abdillah and Jogianto, 2015: 196). Based on the cross-loading test results all the indicators in every latent construct already fulfills the discriminant validity criteria, which is the loading indicator value in a construct that is higher or different with other constructs.

\section{Reliability Test}

A construct is stated to be reliable if the rule of thumb cronbach alpha or composite reliability is greater than 0.7 though a value of 0.6 is still able to be accepted (Abdillah and Jogianto, 2015: 197). Based on reliability tests all constructs have fulfilled the reliable criteria.

\section{Structural Evaluation Model (Research Hypothesis Test)}

The structural evaluation model is implemented by testing the path analysis model that was already validated in Picture 4.1 and Picture 4.2, the data is processed with the aid of smartPLS 3.2.3 software by evaluating the path coefficient value or t-values for every path for a significance test between constructs in a structural model and R-square for dependent constructs. The path coefficient value or inner model shows significance levels in the hypothesis test (Abdillah and Jogiyanto, 2015:197).

The hypothesis test is implemented for observing relations between independent variables, which are information quality and information system quality to dependent variables which are use, system user satisfaction and individual impact. The hypothesis test is implemented with an inner model test with a trust level of $95 \%$ and analysis error of 5\%.The research model in the hypothesis test consists of two research models which are model 1 and model 2.

By using a Bootstrapping method in the SmartPLS 3.2.3 software, it is able to be obtained standard errors, path coefficients and a T-Statistic value. With this 
technique, the researcher is able to rate the statistical significance research model by testing hypothesis for every relation path.

For analyzing relations of every variable or testing research hypothesis a comparison between T-statistic values with T-table values is implemented and a comparing it with the $\mathrm{p}$ value with a significance of 0.05 . If the T-statistic value is more than the T-table and the value of the $\mathrm{P}$-value > alpha $=0.05$ there is a significant influence between variables that are tested. The output from the Bootstrapping method for the model 1 hypothesis test is presented in Table 3.

Table 3 Hypothesis Test Model 1

\begin{tabular}{lccccc}
\hline $\begin{array}{c}\text { Variable } \\
\text { Relations }\end{array}$ & $\begin{array}{c}\text { Original } \\
\text { Sample (O) }\end{array}$ & $\begin{array}{c}\text { Sample } \\
\text { Mean }(M)\end{array}$ & $\begin{array}{c}\text { Standard } \\
\text { Error (STERR) }\end{array}$ & $\begin{array}{c}\text { TStatistics } \\
(\mid \text { OSTERR } \mid)\end{array}$ & P Values \\
\hline KI -> KP & 0.446 & 0.442 & 0.083 & 5.35 & 0.00 \\
KI -> PS & 0.020 & 0.009 & 0.174 & 0.11 & 0.91 \\
KP -> DI & 0.759 & 0.761 & 0.043 & 17.76 & 0.00 \\
KS -> KP & 0.415 & 0.420 & 0.089 & 4.66 & 0.00 \\
KS -> PS & 0.073 & 0.103 & 0.193 & 0.38 & 0.71 \\
PS -> DI & 0.041 & 0.038 & 0.056 & 0.73 & 0.47 \\
PS -> KP & 0.125 & 0.121 & 0.061 & 2.06 & 0.04 \\
\hline
\end{tabular}

Source: PLS Output, processed data, 2016

Based on table 3, shows that information quality has a positive influence to user satisfaction but does not have an influence to use. User satisfaction has a positive influence to individual impact. Information system quality has a positive influence to user satisfaction but does not have an influence to use. System use does not have an influence to individual impact but has an influence to user satisfaction. The output from the Bootstrapping method for the hypothesis test of model 2 is presented in Table 4.

Table 4 Model 2 Hypothesis Test Results

\begin{tabular}{lccccc}
\hline $\begin{array}{c}\text { Variable } \\
\text { Relations }\end{array}$ & $\begin{array}{c}\text { Original } \\
\text { Sample (O) }\end{array}$ & $\begin{array}{c}\text { Sample } \\
\text { Mean }(M)\end{array}$ & $\begin{array}{c}\text { Standard } \\
\text { Error (STERR) }\end{array}$ & $\begin{array}{c}\text { TStatistics } \\
(\mid \text { OSTERR } \mid)\end{array}$ & P Values \\
\hline KI -> KP & 0.449 & 0.435 & 0.078 & 5.79 & 0.00 \\
KI -> PS & -0.142 & -0.162 & 0.172 & 0.83 & 0.41 \\
KP -> DI & 0.759 & 0.757 & 0.039 & 19.38 & 0.00 \\
KP -> PS & 0.350 & 0.364 & 0.169 & 2.07 & 0.04 \\
KS -> KP & 0.424 & 0.449 & 0.074 & 5.70 & 0.00 \\
KS -> PS & -0.075 & -0.077 & 0.192 & 0.39 & 0.70 \\
PS -> DI & 0.041 & 0.049 & 0.064 & 0.65 & 0.52 \\
\hline \multicolumn{5}{c}{ Source: PLS Output, processed data, 2016 }
\end{tabular}


Table 4 shows that information quality has a positive influence to user satisfaction but does not have an influence to use. User satisfaction has a positive influence to individual impact and to use. System quality has a positive influence to user satisfaction but does not have an influence to use. Use does not have an influence to individual impact.

\section{DISCUSSION}

Based on research results to 100 respondents that use the SAS application, research results show that from 8 hypotheses, 5 hypotheses are found to be accepted and 3 hypotheses rejected. Hypotheses that are rejected are hypothesis 1, hypothesis 2 and hypothesis 6 . The discussion is explained in more detail as the following.

\section{Influence of information system quality to information system use}

Test results in this research show proof that the quality of the information system does not influence to information system use. This finding explains that system quality in the SAS application does not influence significantly to system use. The causing factor of the insignificance of system quality influence to this system use, is caused by the SAS application which is a mandatory system. The high level of system use in the SAS application use is not influenced by system quality but pushed because of the obligation for processing financial data and financial reports accurately and on time, for fulfilling regulations in corresponding with the Financial Minister Regulation Number: 210/PMK.05/2013 about Reconciliations in Order.

Financial Report Arrangement of the National General Treasury Environment, where every working unit has an obligation for implementing reconciliations of financial reports every month to the National Treasury Central Office at the latest on the $10^{\text {th }}$ day of the next month. Working units that do not implement reconciliations to the National Treasury Central Office on time an administration punishment will be applied in the form of the cancellation of the publication of the Ordering Letter of Fund Liquidation, of course this will cause delays in the implementation process of the budget and there is a chance it will impact to the decrease in the performance of working units because the realization of the budget absorption is not in accordance with the time schedule planned before.

Another assumption from interview results of rejected hypothesis, other factors that influence the high level of this SAS application use is maybe influenced by the amount of the budget ceiling that is managed by working units. A large budget ceiling makes possible for the treasurers or financial management staff to interact more often with the SAS application and needs more time for operating the application.

Some causing factors of the insignificance of system quality to system use explains that in the use of the SAS application that is a mandatory system, system quality does not become a predictor for system use. This research result does not support the information system success model that is developed by DeLone and McLean (1992), that states that system quality will influence system use. Yet this 
research is consistent with the research implemented by Livari (2005), in his research that is implemented in the information system object that is mandatory, it shows empirical proof that system quality does not predict system use.

\section{Influence of information quality to system use}

The second hypothesis test results show proof that information quality does not have an influence to information system use. Although the user perceives that the SAS application has high quality information and use in a high category, yet the level of use of this system is not influenced by information quality but caused by the SAS application which is a mandatory system application. The high level of use is caused by the treasurers or finance managers that have to operate the SAS application for finishing tasks and obligations, which are obliged to finish financial responsibility reports accurately and on time. Findings in this research show that in the use of the SAS application that is a mandatory system, information quality is not a predictor for system use.

This research result does not support the information system success model that is developed by DeLone and McLean (1992), that states that information quality will influence system use. Yet this research is consistent with the research implemented by Livari (2005), in his research that is implemented in the information system object that is mandatory, it shows empirical proof that information quality does not predict system use.

\section{Influence of information system quality to information system user satisfaction}

Analysis results show that the hypothesis is accepted, this means the SAS system application quality has a positive influence to system user satisfaction. The higher the quality of the SAS application system the higher the system user satisfaction. Results of this research supports the information system success model that is developed by DeLone \& McLean (1992) that states that system quality will influence user satisfaction.

It is able to be explained that if the information system that is used fulfills the expectations of the system user, the user will feel satisfaction using that system. In the use of the SAS application, the treasurers or financial managing staff as system users perceived that the SAS application has a high system quality and able to provide satisfaction to them. For increasing the user satisfaction there is a need to increase the quality of the SAS system application. In increasing system quality the following elements need to bsge paid attention: economy, portability, reliability, understandability, and user-friendliness. The SAS application is said to have a quality system if it is able to increase data processing capability significantly when used, the application is able to run in other computers and able to be used in the environment of another organization without being modified significantly.

For the developing party, in implementing development or updating the system, the SAS application has to be designed to be easily learned by its users, though the user just used it for the first time, it should be easy to learn it and though the user has not used the SAS application since a long time it should be easy to use it again. For guaranteeing data safety, a quality information system has to be 
designed to have a security system so users that do not have a right are unable to access data that are in the system.

\section{Influence of information quality to information system user satisfaction}

Analysis results show that the hypothesis is accepted, this means the SAS system application quality has a positive influence to system user satisfaction. The higher the quality of the SAS application system the higher the system user satisfaction. Results of this research also supports the information system success model that is developed by DeLone \& McLean (1992) that states that information quality will influence user satisfaction.

Findings in this research explains that the SAS application has a high information quality corresponding with the expectations of system users so it is able to provide satisfaction to the treasurers or financial management staff that operate the application. For the user satisfaction to increase, there is a need for increasing information quality that is produced by the SAS application. The Treasury Directorate General of the Finance Ministry of the Republic of Indonesia as the developing institution, if implementing updates to the SAS application in order for increasing the quality of the SAS application the following elements need to be paid attention: accuracy, timeliness, relevance, informativeness and competitiveness.

SAS application users will feel satisfied using the application if the information that is produced by the SAS application is of high quality. The application is able to produce data or information that is accurate, trusted, easily understood, detailed and right that are presented on time.

\section{Influence of system use to information user satisfaction}

Analysis results show that system use has a positive influence to system user satisfaction. This means that the higher the intensity and frequency of using the SAS application the higher the user satisfaction level. Results of this research supports the information system success model that is developed by DeLone \& McLean (1992) that states that use will influence user satisfaction.

System use in this research, only provides a positive influence to user satisfaction as large as $12.9 \%$, indicates that use has a weak influence to user satisfaction. This is caused because system quality and information quality does not predict use, but because the SAS application is mandatory, the application is used because there is an obligation for finishing tasks, a positive experience because use will cause an increase in application user satisfaction. For increasing user satisfaction of the SAS application, the treasurers or financaial management staff in working units are suggested to be able to continuously increase intensity and frequency of the SAS application use so they will feel more satisfied using this application.

\section{Influence of information system user satisfaction to information system use}

Analysis results show that the hypothesis is accepted, this means that there is a positive influence to SAS user satisfaction to the level of system use. This means that the more the user feels satisfied with the SAS application, it causes an increase in intensity and frequency in the SAS application use. Data findings of this research supports the information system success model that is developed by DeLone and 
McLean (1992) that states that user satisfaction will influence use. Results of this research show that the SAS application has already fulfilled user expectations, that is shown with positive relations between user satisfaction and system use, which means user satisfaction will cause system use to increase. For the SAS application use to increase, system user satisfaction needs to be increased. The increase in user satisfaction is implemented with an increase in system quality and information quality of the SAS application.

\section{Influence of information system use to individual impact}

Analysis results show that the hypothesis is rejected, this means that there is no influence of system use to individual impact. The higher the level of system use, individual impact will not be influenced. This occurs because the SAS application is a mandatory system application, which means the treasurers or financial management staff have to use the SAS application to finish their tasks. The treasurers or financial management staff are charged for finishing tasks accurately, reliable and on time because based on the Financial Minister Regulation Number: 210/PMK.05/2013 about Reconciliations in Order in the Financial Report Arrangement of the National General Treasury Environment states that acceptance and expenditure treasurers have an obligation for presenting the Financial Responsibility Report that is implemented at the latest on the $10^{\text {th }}$ day of the next month and presented to the National Treasury Central Office as the attorney of the National General Treasury that is chosen in the Budget Ceiling Contents List a unit below its management; Minister/leader of each body and the Financial Investigation Bureau of Indonesia. This explains that in the use of the SAS application that is mandatory, the high level of system use does not have an influence to individual impact so it is able to be summarized that in the SAS application use, system use is not as a significant predictor to individual impact.

This research result does not support the information system success model that is developed by DeLone and McLean (1992) that states that system use has an influence to individual impact, Yet, this research's results supports criticism that is stated in Seddon's research (1997) that states that use is a clarification of behavior not as a measure of information system success so use is not a valid interpretation from the D\&M IS Success Model. Petter et.al (2008), also stated that use frequency is maybe not the best way to measure information system success.

\section{Influence of information system user satisfaction to individual impact}

Analysis results show that the hypothesis is accepted, this means that there is a positive influence to user satisfaction. The higher the SAS application user satisfaction, the higher the benefit/impact that is felt by the individual system user. Results of this research supports the information system success model that is developed by DeLone and McLean (1992) that states that user satisfaction influences individual impact.

Findings in this research show that user satisfaction predicts as large as $65 \%$ to individual impact. This explains that by using the SAS application the treasurers and financial managers feel benefit or impact that is shown by the high level of satisfaction that is felt that will increase their performance. With the presence of the SAS application, the user will be able to perform their work activities 
effectively and efficiently and also obtain work results that are more effective and efficient. For increasing individual impact system user satisfaction needs to be increased. In increasing system user satisfaction, it is able to be implemented by increasing system quality and information system quality and needs to be able to increase system use. This is shown with findings in this research that as a whole the system quality variable, information quality and use predicts use satisfaction as large as $65 \%$ and individual impact is predicted by user satisfaction as large as $59 \%$.

As a whole, findings in this research show that the highest predictor of the SAS application use success model is user satisfaction which is as large as $65 \%$ and the second is individual impact which predicts as large as $59 \%$ so it is able to be summarized that the prediction categories of user satisfaction and individual impact are in the moderate category (Ghozali, 2015:78). The system use variable in this research is found to not have a significant influence to individual impact, this means that use does not predict the success of the SAS application use. Therefore, results of this research explains that in the use of the SAS application that is a mandatory system reviewed from the system user perception, it is able to be summarized that what influences the success of the SAS application use in working units in the Bengkulu National Treasury Central Office is the system quality variable, information quality, user satisfaction and individual impact.

\section{CONCLUSSION}

This research has a purpose for testing factors that influence the success of the SAS application reviewed from the system user perception by adapting the information system success model that is developed by DeLone and McLean (1992). Based on the results of this research summary is able to be obtained that (1) Information system quality does not influence information system use, (2) Information quality does not have a positive influence to information system use, (3) Information system quality has an influence to information system user satisfaction, (4) information quality has a positive influence to information system user satisfaction, (5) Information system user satisfaction has a positive influence to information system use (6) information system use has a positive influence to information system user satisfaction, (7) Information system use does not influence significantly to individual impact, and (8) information system user satisfaction influences positively to individual impact.

The presence of system quality influence and information quality to user satisfaction and individual impact is influenced by user satisfaction, so the better the system quality and information quality, the user satisfaction level will be higher that will increase individual impact. Because of that the Treasury Directory General of the Indonesian Ministry of Finance as the developer of the SAS application in implementing system development has to be able to increase system quality and information quality of the SAS application to obtain a high level of SAS application user satisfaction so it will increase the benefit or impact for individual SAS application users. The system quality increase that need to be paid attention are the factors: economy, portability, reliability, understandability, and user-friendliness. 
The information quality increase needs to pay attention to the factors: accuracy, timeliness, relevance, and informativeness.

The presence of a reciprocal influence between use and user satisfaction, as a process model and a causal model, The increase in use will increase user satisfaction and will cause an increase in use interest and then will use. Because of that for system users which are treasurers or financial management staff that operate the SAS application, they have to increase the intensity and frequency of system use continuously so that user satisfaction will increase so it will cause the increase of individual impact of system users in the form of an increase in performance quality of users individually including productivity, efficiency, and effectiveness of performance inside.

\section{References}

Abdillah, Willy., \& H.M, Jogiyanto. (2015). Partial Least Square (PLS): Alternatif Structural Equation Modeling (SEM) dalam Penelitian Bisnis. Yogyakarta: ANDI

Bailey,J.E., \& S.W., Pearson. (1983). Development of a Tool for Measuring and Analyzing Computer User Satisfaction. Management Science, 29 (May).

Bodnar, George H., William, S., \& Hopwood. (2010). Accounting Information System (10th edition). United State America: Pearson Education Inc.

Davis, F.D. (1989). Perceived Usefulness, Perceived Ease of Use, and UserAcceptance of Information Technology. MIS Quarterly, (13:3), 319340.

DeLone, W.H., \& McLean, E.R. (1992). Information Systems Success: The Quest For The Dependent Variable. Information Systems Research, 60-95.

DeLone, W.H., \& McLean, E.R. (2003). The DeLone and McLean Model of Information System Succes: A ten-Year Update. Information Systems Research, 9-30

Ghozali, Imam. (2015). Partial Least Squares, Konsep, Teknik Dan Aplikasi Menggunakan Program Smartpls 3.0 Untuk Penelitian Empiris. Semarang: Badan Penerbit UNDIP

H.M, Jogiyanto. (2007). Model Kesuksesan Sistem Teknologi Informasi. Yogyakarta: Andi.

H.M, Jogiyanto. (2008). Metodologi Penelitian Sistem Informasi. Yogyakarta: Andi

Istianingsih., \& Wijanto,S.H. (2008a). Pengaruh Kualitas Sistem Informasi, Perceived Usefulness, dan Kualitas Informasi Terhadap Kepuasan Pengguna Akhir Software Akuntansi. Simposium Nasional Akuntansi 11 Pontianak.

Istianingsih., \& Wijanto,S.H. (2008b). Analisa Keberhasilan Penggunaan Perangkat Lunak Akuntansi Ditinjau Dari Persepsi Pemakai (Studi Implementasi Model Keberhasilan Sistem Informasi). Jurnal Akuntansi dan Keuangan Indonesia, 5(1).

Istianingsih., \& Wiwik, Utami. (2009). Pengaruh Kepuasan Pengguna Sistem Informasi Terhadap Kinerja Individu (Studi Empiris pada Pengguna Paket Program Aplikasi Sistem Informasi Akuntansi di Indonesia). Simposium Nasional Akuntansi 12. 
Ivari, J., \& Koskela, E. (1987). The PIOCO Model for Information System Design. MIS Querterly, 11(3), 401-419.

J.E. (2003). User Developed Applications and Information Systems Success: A Test of DeLone and McLean's Model. Information Resources McGill T.J, Hobbs V.J, and Klobas Management Journal, 16(1), 24-45.

Jumardi, Nugroho., \& Hidayah. (2015). Analisis Kesuksesan Implementasi Sistem Informasi Skripsi pada Program Studi Teknik Informatika Universitas.

Pembangunan Nasional "Veteran" Yogyakarta. Seminar Nasional Aplikasi Teknologi Informasi. ISSN:1907-5022

Livari, Juhadi. (2005). An Empirical Test of The Delone and Mclean Model of Information System Sucsess. Database for Advances in Information System. Spring, 36(2), 8.

Mason, R.O. (1978). Measuring Inforation Output: A Communication Systems Approach. Information and Management, (1:5), 219-234.

Mulyono. (2009) . Uji Empiris Model Kesuksesan Sistem Informasi Keuangan Daerah (SIKD) dalam Rangka Peningkatan Transparansi dan Akuntabilitas Keuangan Daerah. Simposium Nasional Akuntansi XII. Palembang.

Myers B.L., Kappleman L.A., \& Prybutok V.R. (1997). Comprehensive Model For Assessing The Quality and Productivity of The Information Systems Function: Toward a Contingency Theory For Information Systems Assessment. Information Resources Management Journal, 10(1), 6-25.

Peraturan Dirjen Perbendaharaan No. PER-3/PB/2014 tentang Petunjuk Teknis Penatausahaan, Pembukuan, dan Pertanggungjawaban Keuangan. Direktorat Jenderal Perbendaharaan. Jakarta

Peraturan Menteri Keuangan 210/PMK.05/2013 Tentang Pedoman Rekonsiliasi Dalam Rangka Penyusunan Laporan Keuangan Lingkup Bendahara Umum Negara dan Kementerian Negara/Lembaga. Menteri Keuangan Republik Indonesia. Jakarta

Peraturan Menteri Keuangan No.162/PMK.05/2013 tentang Kedudukan dan Tanggung Jawab Bendahara dalam APBN. Menteri Keuangan Republik Indonesia. Jakarta

Petter, Stacie., DeLone, W.H., \& McLean, E.R. (2008). Measuring information systems success: models, dimensions, measures, and interrelationships. European Journal of Information Systems, 17, 236-263.

Radityo., \& Zulaikha. (2007). Pengujian model DeLone and McLean dalam pengembangan Sistem Informasi Manajemen (Kajian Sebuah Kasus). Simposium Nasional Akuntansi X. UNHAS Makasar.

Rahadi, D.R. (2007). Peranan Teknologi Informasi Dalam Peningkatan Pelayanan Sektor Publik. Seminar Nasional Teknologi 2007 (SNT 2007). ISSN : 1978 $-9777$.

Rai, A., Lang, S.S., \& Welker, R.B. (2002). Assessing The Validity of IS Success Models: An Empirical Test and Theoretical Analysis. Information System Research, 13(1), 29-34.

Romney, Marshal B., \& Steinbart, Paul John. (2015). Sistem Informasi Akuntansi: Accounting Information Systems $\left(13^{\text {th }}\right.$ ed), Terjemahan oleh Kikin Sakinah Nur Safira dan Novita Puspitasari. Jakarta: Salemba Empat.

Sander,G.L., \& Courtney,J.F. (1985). A Field Study of Organizational Factors Influencing DSS Succes. MIS Quarterly, (9:1), 77-93. 
Seddon, P. (1997). A Respecification and Extension of The DeLone and McLean Model of IS Success. Information Systems Research, 8(3), 240-253.

Seddon, P., \& Kiew M Y. (1994). A Partial Test and Development of The DeLone and McLean Model of IS Success. ICIS, 99-110.

Srinivasan, A. (1985). Alternative Measures of System Effectiveness: Associations and Implications. MIS Quarterly, (9:3), 243-253..

Sugiyono. (2014). Metode Penelitian Kombinasi (Mixed Methods). Bandung: Penerbit Alfabeta.

Tan, Suyatno., \& Aliyah. (2015). Pengujian Kesuksesan Sistem Informasi DeLone \& McLean Pada Sektor Publik. University Research Colloquium. ISSN 2407-9189

Wahyuni. (2011). Uji Empiris Model Delone dan Mclean Terhadap Kesuksesan Sistem Informasi Manajemen Daerah (SIMDA). Jurnal BPPK, 2.2

Widjajanto, Nugroho. (2001). Sistem Informasi Akuntansi. Jakarta: Gelora Aksara Pratama.

http://sahabatsatker.com/apa-itu-aplikasi-sas-perbendaharaan. diakses tanggal 10 September 2015

http://www.bendahara-kotabaru.blogspot.co.id/2015/04/aplikasi-sas-utility.html. diakses tanggal 10 September 2015 